\title{
Pengaruh senam aerobik dan yoga terhadap rasio lingkar pinggang panggul dan tingkat depresi pada wanita primenopause
}

\author{
Danang Supratmanto *, B.M. Wara Kushartanti \\ Program Studi Ilmu Keolahragaan, Program Pascasarjana, Universitas Negeri Yogyakarta. \\ Jalan Colombo No. 1, Karangmalang, Yogyakarta, 55281, Indonesia \\ * Corresponding Author. Email: danang_s27@yahoo.com
}

Received: 30 July 2018; Revised: 6 November 2018; Accepted: 17 November 2018

\begin{abstract}
Abstrak
Penelitian ini bertujuan untuk (1) mengetahui seberapa jauh efektivitas antara senam aerobik dan yoga terhadap penurunan Rasio Lingkar Pinggang Panggul (RLPP) dan penurunan tingkat depresi pada wanita perimenopause, (2) mengetahui mana yang paling efektif dari senam aerobik dan yoga terhadap penurunan RLPP dan penurunan tingkat depresi pada wanita perimenopause. Penelitian ini merupakan penelitian true-eksperimental design dengan desain tiga kelompok dengan tes awal dan tes akhir serta kelompok kontrol. Subjek penelitian ini adalah wanita yang memasuki masa perimenopause, usia mulai 40 tahun. Teknik pengambilan sampel menggunakan probability sampling dengan jenis tipe simple random sampling dengan total responden sebanyak 60 orang. Instrumen pengumpulan data menggunakan tes pengukuran skala DASS untuk depresi, dan pita ukur dengan rumus RLPP. Analisis data menggunakan uji t-paired sample dan uji ANOVA. Hasil penelitian menunjukkan bahwa (1) senam aerobik tidak efektif untuk menurunkan RLPP dan tingkat depresi pada wanita perimenopause $(p>0,05)$. Yoga tidak efektif menurunkan RLPP $(p>0,05)$, tetapi efektif menurunkan tingkat depresi $(p<0,005)$; (2) tidak ada jenis latihan paling efektif menurunkan RLPP pada wanita perimenopause. Jenis latihan paling efektif menurunkan tingkat depresi pada wanita perimenopause adalah yoga.
\end{abstract}

Kata Kunci: aerobik, yoga, RLPP, depresi, wanita perimenopause

\section{The influence of aerobic gymnastic and yoga on the waist-to-hip ratio and the depression level among pre-menopause women}

\begin{abstract}
The study aims at: (1) identifying how effective aerobic and yoga exercise is in decreasing the waistto-hip ratio (WHR) and the depression level among the pre-menopause women; and (2) identifying which exercise is more effective, between the aerobic exercise and the yoga exercise, in decreasing the waist-to-hip ratio (WHR) and depression level among the pre-menopause women. The study itself was a true-experimental design with pre-test and post-test control group design. Then, the subjects in the study were the women who entered their pre-menopause age, starting from 40 years old. The samples for the study were gathered by means of probability sampling technique with simple random sampling technique and the total respondents in the study were 60 people. Next, the data for the study were gathered through RLPP formula with measurement tape for the assessment of waist-to-hip ratio and the administration of DASS scale measurement test for the assessment of depression level. The data that had been gathered were analysed using the t-paired sample test and the ANOVA test. The results of the study show that: (1) the aerobic exercise is not effective in decreasing the waist-to-hip ratio and the depression level among the pre-menopause women ( $p>0.05)$ while the yoga exercise is not effective in decreasing the waist-to-hip ration but is effective for decreasing the depression level among the pre-menopause women ( $<$ 0.005); and (2) there is not any kind of most effective exercise in decreasing the waist-to-hip ratio among the pre-menopause women. However, yoga can be the most effective exercise in decreasing the depression level among the pre-menopause women.
\end{abstract}

Keywords: aerobic, yoga, WHR, depression, perimenopause women.

How to Cite: Supratmanto, D., \& Kushartanti, B. (2018). Pengaruh senam aerobik dan yoga terhadap rasio lingkar pinggang panggul dan tingkat depresi pada wanita primenopause. Jurnal Keolahragaan, 6(2), 172-183. doi:https://doi.org/10.21831/jk.v0i0.20616

doi https://doi.org/10.21831/jk.v0i0.20616 


\section{PENDAHULUAN}

Pada rentang umur setiap wanita akan menghadapi beberapa masalah kesehatan, baik dari kodisi fisiknya maupun psikologisnya. Salah satu masalah yang akan dihadapi adalah masuknya wanita di masa menopause. Sebelum ke masa menopause akan menghadapi dulu masa perimenopause, dimana wanita akan timbul banyak permasalahan (Putri \& Hamidah, 2012, p.2). Permasalahan yang timbul saat perimenopause adalah terjadinya perubahan fisik yang berpengaruh terhadap kondisi psikologis. Perubahan fisik yang terjadi salah satunya kegemukan pada wanita, yang sering terlihat adalah lingkar pinggang panggul yang semakin melebar. Perubahan ini mempengaruhi psikologis para wanita sehingga akan timbul rasa tidak percaya diri, pemarah, stres, bosan, dan yang sering terlihat adalah munculnya depresi. Perubahan semua ini mengakibatkan turunnya aktivitas fisik yang menjadikan malas untuk beraktivitas dan menurunnya kinerja sehari-hari (Kaplan, Sadock, \& Grebb, 2010, pp. 17-35).

Turunnya aktivitas fisik akan berakibat buruk untuk kesehatan seperti yang dilaporkan oleh Nied dan Franklin bahwa di Amerika Serikat populasi wanita dengan kehidupan inaktif dan kurang beraktivitas fisik meningkat mencapai 75\% dari jumlah wanita perimnopause. Kehidupan ini mengakibatkan kemampuan fungsional organ tubuh setelah umur 30 tahun dan akan mengalami penurunan sebesar $1 \%$ per tahun. Perubahan ini mempengaruhi beberapa komponen seperti ketahanan paru jantung, kekuatan otot, dan komposisi badan. Komponen ini dapat dijaga dengan melakukan olahraga, dimana olahraga berfungsi untuk meningkatkan dan mempertahankan kebugaran fisik. Hal ini diperkuat dengan pendapat Budiyono, (2015, p. 78), bahwa olahraga yang dianjurkan untuk wanita perimenopause adalah jalan kaki, jogging, senam, renang dan fitness, berbagai macam olaharaga yang direkomendasikan, olahraga yang baik digunakan oleh para wanita perimenopause adalah senam.

Senam sangat bermanfaat untuk wanita perimenopause karena dapat menurunkan tekanan darah tinggi yaitu dengan mengurangi berat badan dan mengelola stres, dua faktor yang mempertinggi hipertensi, dengan melakukan gerakan yang tepat selama 30-40 menit atau sebanyak minimal 3 hari dan maksimal 4 hari perminggu dapat menurunkan tekanan darah sebanyak $10 \mathrm{mmHg}$ pada bacaan sistolik dan diastolic (Fatmah, 2011, p.35). Salah satu senam yang dilakukan oleh para wanita perimenopause adalah senam aerobik. Senam aerobik merupakan alternatif untuk wanita perimenopause menurunkan berat badan yang sampai saat ini masih populer di masyarakat. Senam aerobik dapat memberikan hasil yang maksimal jika dilakukan dengan frekuensi, intensitas dan durasi yang cukup. Seperti yang diungkapkan oleh Dinata (2007, p.18) bahwa frekuensi latihan sebaiknya 3-4 kali dalam seminggu. Kurang dari 3 kali dianggap kurang memadai dalam frekuensi dan lebih dari 5 kali dianggap berlebihan. Semua ini harus terprogram karena manfaatnya sangat besar khususnya untuk wanita perimenopause. Manfaat pada tubuh wanita perimenopause bisa memperbaiki kerja jantung agar lebih efisien, memperkuat otot, daya tahan otot, kelenturan serta komposisi tubuh yang baik (Brick, 2001, p. 4). Belum tahunya wanita perimenopause dalam senam aerobik yang menyebabkan wanita perimenopause mengeluh, sehingga berakibat depresi. Depresi yang timbul membuat wanita perimenopause malas untuk melakukan aktifitas fisik, sehingga malas bergerak atau berolahraga untuk melakukan senam aerobik. Tidak teraturnya berolahraga berefek ke perubahan fisik yang mengakibatkan lebar lingkar pinggang panggul meningkat dan berat badan juga meningkat.

Selain senam aerobik ada senam lainnya yang sering dilakukan oleh wanita perimenopause yaitu senam yoga. Senam yoga merupakan intervensi holistic yang menggabungkan postur tubuh (asanas), teknik pernapasan (pranayamas) dan meditasi. Yoga sangat diminati di kalangan para wanita, khususnya yang sudah masuk di masa perimenopause, karena intervensi senam yoga sangat efektif dalam mengurangi berat badan, tekanan darah, kadar glukosa dan kolesterol tinggi, serta pikiran, relaksasi fisik dan emosional. Senam yoga dan senam aerobik sangat membantu untuk menanggulangi kejadian yang dialami oleh para wanita perimenopause yaitu, perubahan dan ketidaknyamanan atas diri meningkat karena adanya pengaruh penurunan hormon estrogen dibandingkan fase-fase lainnya karena fungsi ovarium juga menurun. Perubahanperubahan inilah yang membuat munculnya sikap negatif terhadap perimenopause karena wanita khawatir tentang perimenopause dan beranggapan akan kehilangan daya tarik serta khawatir orang-orang yang dicintainya akan meninggalkannya. Apalagi yang jarang mengenal atau melakukan senam yoga, wanita perimenopause tidak akan bisa mengantur kemarahan 
setiap harinya, apalagi dengan lebar pinggang panggul yang meningkat membuat wanita perimenopause depresi yang tinggi.

Perimenopause merupakan masa sebelum menopause dimana mulai terjadi perubahan endokrin, biologis, dan gejala klinis sebagai awal permulaan dari menopause dan mencakup kurang dari satu tahun atau dua belas bulan pertama setelah berhentinya menstruasi. Mengingat usianya yang sudah matang umumnya kondisi fisiknya menjadi menurun, seperti halnya pada wanita perimenopause yang memasuki rentang usia 40 hingga 55 tahun. Fenomena ditandai dengan berhentinya siklus bulanan menstruasi dan sejumlah gejala seperti sakit kepala, pendarahan dan sejumlah masalah lainya bisa muncul. Sekitar separuh dari semua wanita mentruasi mulai tidak teratur antara usia 40 dan 55, sekitar seperempat berhenti sebelum umur 45 tahun, dan seperempat lainnya terus menstruasi sampai melewati umur 55 tahun. Gejala yang timbul membuat wanita perimenopause melakukan olahraga untuk menurunkan timbulnya perubahan fisik yang terjadi di lingkar pinggang panggul. Olahraga menjaga kebugaran tubuh dan menjaga berat badan tetap stabil sehingga wanita memiliki tubuh yang ideal. Pernyataan ini konsisten dengan penelitian yang dilakukan pada wanita menopause di Amerika, yang menunjukkan adanya penurunan kadar estradiol sebesar 7,7 \% setelah olahraga selama 3 bulan dan $4,4 \%$ setelah 12 bulan. Hasil ini juga sesuai dengan hasil penelitian dari Mawi, et.al. (2009, p. 122) bahwa mekanisme terjadinya penurunan kadar estradiol pada wanita perimenopause yang melakukan olahraga adalah olahraga aerobik dan yoga yang mampu menurunkan lemak dalam tubuh. Penurunan lemak ini mengakibatkan menurunnya produksi estrogen dari androgen di jaringan lemak melalui proses aromatisasi.

Dari hasil survei dengan pengamatan dan tanya jawab kasus tersebut sama halnya dengan wanita-wanita yang menganjak masa perimenopause di Desa Banjarejo, Kecamatan Bayan, Kabupaten Purworejo sebagai berikut: (1) kehilangan daya tarik serta khawatir orang-orang yang dicintainya akan meninggalkannya, (2) wanita merasa dirinya sudah tidak menarik lagi dan sudah tidak keibuan lagi, (3) munculnya gejala rasa takut, tegang, sedih, lekas marah, mudah tersinggung, gugup, stres dan depresi, (4) wanita yang mengalami masa perimenopause mengalami perubahan fisik. Perubahan fisik dan psikologis yang terjadi dialami oleh wanita perimenopause menjadikan wanita untuk melakukan olahraga yang teratur diyakini bisa mengurangi resiko seperti pendarahan dan bahkan mengurangi resiko lainya sebagai dampak dari gejala menopause. Mengkritisi sejumlah wanita yang tengah menghadapi gejala perimenopause yang tidak teratur melakukan olahraga, akan berakibat turunnya tingkat hormon estrogen pada wanita yang mengalami gejala perimenopause juga akan memberikan resiko terjadinya kenaikan berat badan pada para wanita itu. Hasil dari pengamatan tersebut, untuk mengetahui seberapa jauh efektivitas antara senam aerobik dan yoga terhadap penurunan lingkar pinggang panggul dan penurunan tingkat depresi pada wanita perimenopause. Mengetahui mana yang paling efektif dari senam aerobik dan yoga terhadap penurunan lingkar pinggang panggul dan penurunan tingkat depresi pada wanita perimenopause.

\section{METODE}

Penelitian ini merupakan penelitian TrueExperimental Design dengan desain tiga kelompok dengan tes awal dan tes akhir serta kelompok kontrol (Pretest-Postest Control Group Design). Penelitian dilaksanakan di Balai Desa Banjarejo, Kecamatan Bayan, Kabupaten Purworejo, bulan Desember 2017.

Jumlah subjek adalah sebanyak 60 wanita perimenopause, subjek penelitian diambil secara purposive sampling. Ada 20 orang diberikan perlakuan senam aerobik, 20 orang diberikan perlakuan yoga dan 20 orang yang tanpa pemberian perlakuan senam aerobik dan yoga.

Data yang dikumpulkan dalam penelitian ini adalah data yang didapat dengan menggunakan tes dan pengukuran dari wanita perimenopause. Instrumen yang digunakan lingkar perut adalah Rasio Lingkar Pinggang-Panggul (RLPP) dan untuk mengukur tingkat depresi dalam penelitian ini menggunakan skala DASS (The Depression Anxiety Stress Scales). Berdasarkan hasil uji validitas instrumen, menunjukkan bahwa semua item memiliki koefisien korelasi ( $\mathrm{r}_{\text {hitung }}$ ) bernilai positif dan lebih besar dari $r_{\text {tabel }}=0,361$ yang berarti valid. Reliabilitas diperoleh koefisien Alpha Cronbach, kuesioner tingkat depresi pada wanita perimenopause sebesar 0,954.

Data yang diperoleh dari hasil pengukuran dianalisis dengan menggunakan uji prasyarat analisis yaitu uji normalitas untuk mengetahui data normal atau tidak dan uji homogenitas untuk mengetahui bahwa data homogen atau tidak. Data yang diperoleh dari hasil pengukuran dianalisis dengan menggunakan uji-t (beda) berpasangan (paired t-test) dengan taraf signifikasi 
$5 \%$. Uji-t menghasilkan nilai $t$ dan nilai probabilitas (p) yang dapat digunakan untuk membuktikan hipotesis ada atau tidak adanya pengaruh secara signifikan dengan taraf signifikasi $5 \%$. Cara menentukan signifikan tidaknya adalah jika nilai $\mathrm{p}<0,05$ maka ada perbedaan signifikan, jika $\mathrm{p}>0,05$ maka tidak ada perbedaan signifikan, selanjutnya data dianalisis menggunakan program uji anova.

\section{HASIL DAN PEMBAHASAN}

Deskripsi data yang akan dijabarkan berupa data hasil pengukuran Rasio Lingkar Pinggang Panggul (RLPP) dan tingkat depresi sebelum dan sesudah diberikan perlakuan pada masing-masing kelompok, serta data delta atau perubahan RLPP dan tingkat depresi pada setiap kelompok perlakuan.

Deskripsi subyek penelitian bertujuan untuk mendeskripsikan karakteristik demografi subyek meliputi data umur, pekerjaan dan pendidikan. Gambaran karakteristik demografi responden menjadi penguat data penelitian. Hasil analisis deskripsi subjek penelitian dapat dilihat pada Tabel 1.

Pada Tabel 1 diketahui dari 60 wanita perimenopause dalam penelitian ini rata-rata berumur 50,35 dengan standar deviasi sebesar 3,15 . Distribusi umur terbanyak pada umur $45-48$ tahun dengan 21 wanita perimenopause (35\%), pada umur tersebut wanita banyak timbul gejala yang dikeluhkan wanita perimenopause dan golongan umur tersebutlah wanita masuk mengalami masa perimenopause. Diketahui dari 60 wanita perimenopause paling banyak adalah ibu rumah tangga $(31,7 \%)$. Sebagian kecil bekerja sebagai guru $(5 \%)$ dan buruh $(11,7 \%)$. Diketahui dari 60 wanita perimenopause paling banyak berpendidikan SMA/SMK (65\%). Sebagian kecil berpendidikan S-1 (5\%).

Pada Tabel 2 hasil analisis diketahui dari 60 wanita perimenopause dalam penelitian ratarata berat badan pada saat pretest sebesar 68,71 $\mathrm{kg}$ dengan standar deviasi sebesar 4,65. Distribusi berat badan dalam Tabel 7, diketahui berat badan $65-73 \mathrm{~kg}$ lebih banyak dari berat badan 74 $81 \mathrm{~kg}$. Pada data posttest diketahui 60 wanita perimenopause dalam penelitian rata-rata berat badan sevesar $67,86 \mathrm{~kg}$ dengan standar deviasi 5,59. Distribusi berat badan dalam Tabel 7, diketahui besar badan $65-73 \mathrm{~kg}$ lebih banyak dari berat badan $74-81 \mathrm{~kg}$. Secara lebih jelas dapat dilihat pada Gambar 1.

Tabel 1. Deskripsi Subjek Penelitian

\begin{tabular}{|llccc|}
\hline & Kelompok & Frekuensi & Presentase & Keterangan \\
\hline Umur & 45-48 tahun & 21 & 35,0 & Mean: 50,35 \\
& 49-52 tahun & 20 & 33,3 & SD: 3,15 \\
& 53-55 tahun & 19 & 31,7 & \\
Pekerjaan & Total & 60 & 100 & \\
& IRT & 19 & 31,7 & \\
& Petani & 17 & 28,3 & \\
& Pedagang & 14 & 23,3 & \\
& Guru & 3 & 5,0 & \\
& Buruh & 7 & 11,7 & \\
& Total & 60 & 100 & \\
& SD & 6 & 10,0 & \\
& SMP & 12 & 20,0 & \\
& SMA/SMK & 39 & 65,0 & \\
& S-1 & 3 & 5,0 & \\
& Total & 60 & 100 & \\
& & &
\end{tabular}

Tabel 2. Deskripsi Berat Badan Subjek Penelitian

\begin{tabular}{clllll}
\hline \multirow{2}{*}{ Diskripsi } & \multirow{2}{*}{ Kategori } & \multicolumn{2}{c}{ Pretest } & \multicolumn{2}{c}{ Posttest } \\
\cline { 2 - 6 } & & Frekuensi & Persentase & Frekuensi & Persentase \\
\hline Berat Badan & $56-64 \mathrm{Kg}$ & 11 & 18,3 & 13 & 21,7 \\
& $65-73 \mathrm{Kg}$ & 39 & 65,0 & 36 & 60,0 \\
& $74-81 \mathrm{Kg}$ & 10 & 16,7 & 11 & 18,3 \\
& Total & 60 & 100 & 60 & 100 \\
& & Mean & 68,71 & Mean & 67,86 \\
& SD & 4,65 & SD & 5,59 \\
\hline
\end{tabular}


Jurnal Keolahragaan 6 (2), 2018 - 176

Danang Supratmanto, B.M. Wara Kushartanti

Tabel 3. Deskripsi Data pada Masing-Masing Kelompok Perlakuan

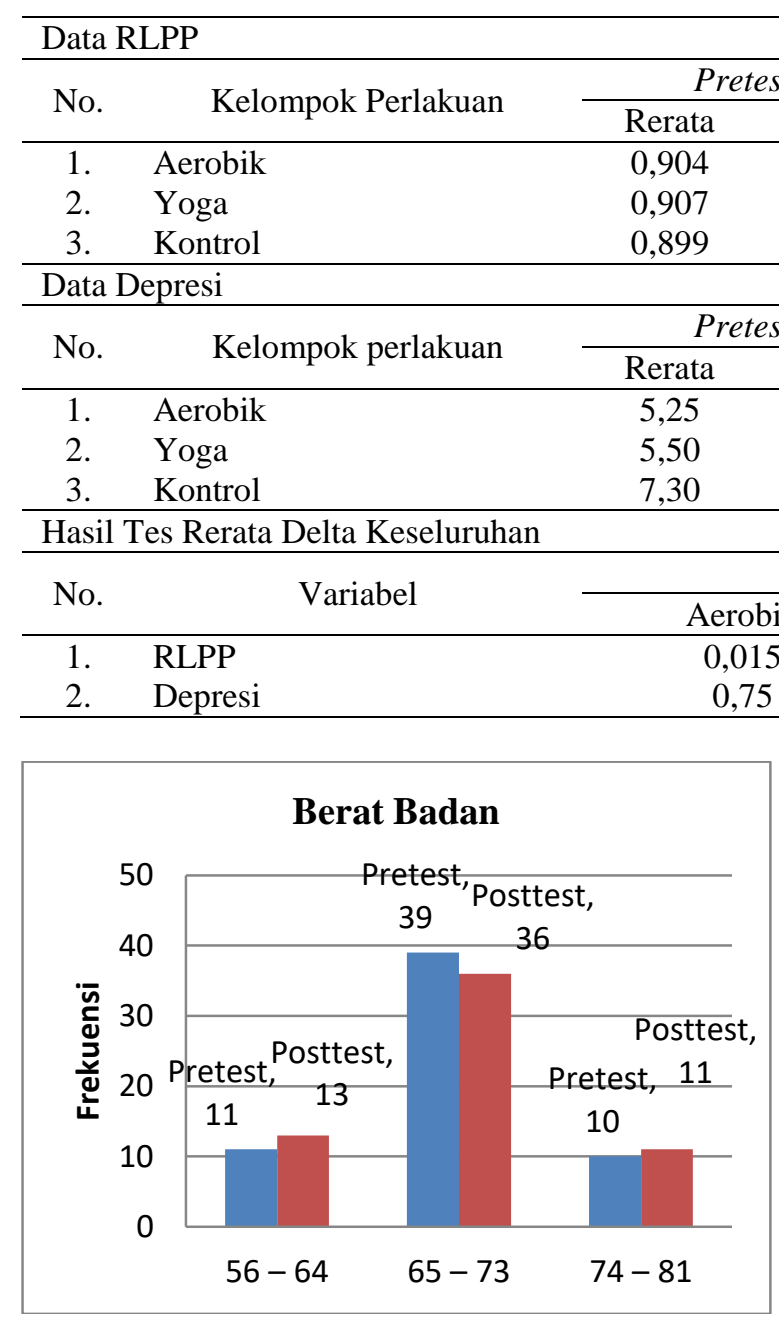

Gambar 1. Berat Badan Wanita Perimenopause Saat Pretest dan Posttest

Penelitian ini bertujuan mengkaji tentang pengaruh senam aerobik dan yoga terhadap penurunan rasio lingkar pinggal panggul (RLPP) dan tingkat depresi pada wanita perimenopause. Data penelitian dianalisis secara deskriptif dengan tujuan untuk memberikan gambaran data penelitian serta untuk mempermudah penyajian data penelitian. Hasil analisis deskriptif pada data penelitian ada pada Tabel 3.

Pada Tabel 3, diketahui penurunan nilai rerata rasio lingkar pinggal panggul paling besar pada kelompok aerobik dan penurunan rerata rasio lingkar pinggal panggul paling kecil pada kelompok yoga. diketahui penurunan nilai rerata depresi paling besar pada kelompok yoga dan penurunan rerata depresi paling kecil pada kelompok tanpa perlakuan. Hasil delta rerata RLPP pada setiap kelompok dapat digambarkan pada Gambar 2.

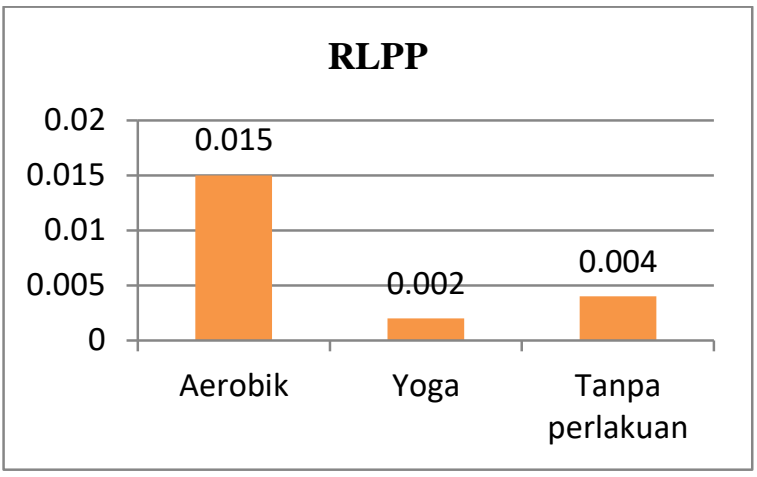

Gambar 2. Hasil Rerata Delta RLPP Setiap Kelompok

Dapat diketahui penurunan tingkat depresi pada kelompok aerobik sebesar 0,015 . Penurunan tingkat depresi pada kelompok yoga sebesar 0,002 dan penurunan pada kelompok tanpa perlakuan sebesar 0,004. Dapat disimpulkan kelompok aerobik paling besar mengalami penurunan RLPP.

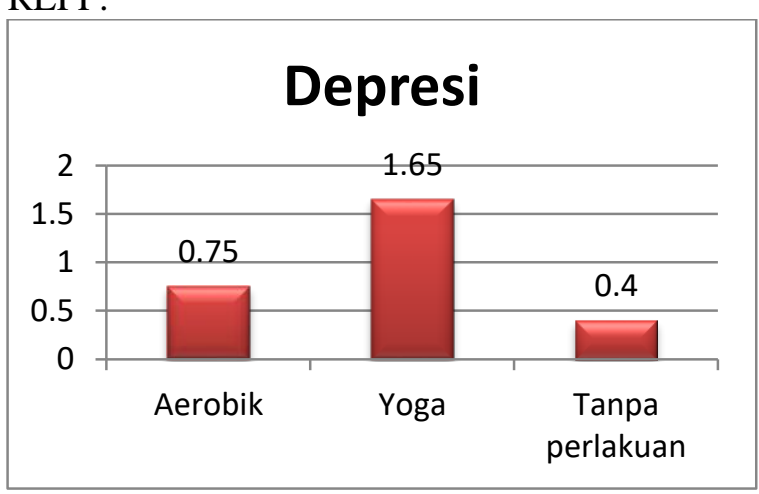

Gambar 3. Hasil Rerata Delta Tingkat Depresi Setiap Kelompok

Diketahui penurunan tingkat depresi pada kelompok aerobik sebesar 0,75. Penurunan 
tingkat depresi pada kelompok yoga sebesar 1,65 dan penurunan pada kelompok tanpa perlakuan sebesar 0,4. Dapat disimpulkan kelompok yoga paling besar mengalami penurunan tingkat depresi. Hasil delta rerata tingkat depresi pada setiap kelompok dapat digambarkan pada Gambar 3.

Berdasarkan Gambar 3, dapat diketahui penurunan tingkat depresi pada kelompok aerobik sebesar 0,75. Penurunan tingkat depresi pada kelompok yoga sebesar 1,65 dan penurunan pada kelompok tanpa perlakuan sebesar 0,4. Dapat disimpulkan kelompok yoga paling besar mengalami penurunan tingkat depresi.

Uji Normalitas

Uji normalitas dilakukan untuk menguji apakah variabel yang dianalisis mempunyai sebaran data yang berdistribusi normal atau tidak. Uji normalitas data dilakukan menggunakan Kolmogorov Smirnov Z. Pembacaan hasil data dikatakan normal apabila $p$ value (Sig.) $>0.05$. Hasil uji normalitas ditunjukkan pada tabel 4.

Tabel 4. Hasil Uji Normalitas Data Setiap Kelompok

\begin{tabular}{clccc}
\hline \multicolumn{6}{c}{ Kelompok Aerobik } & & & \\
\hline Pengamatan & Variabel & KSZ & Sig. & Ket. \\
\hline \multirow{2}{*}{ Pretest } & RLPP & 0,596 & 0,870 & Normal \\
& Depresi & 1,076 & 0,197 & Normal \\
Posttest & RLPP & 0,546 & 0,927 & Normal \\
& Depresi & 0,827 & 0,500 & Normal \\
Kelompok Yoga & & & \\
\hline Pengamatan & Variabel & KSZ & Sig. & Ket. \\
\hline \multirow{5}{*}{ Pretest } & RLPP & 0,581 & 0,888 & Normal \\
& Depresi & 0,942 & 0,338 & Normal \\
Posttest & RLPP & 0,556 & 0,917 & Normal \\
Kelompok Tanpa Perlakuan & 0,883 & 0,416 & Normal \\
\hline Pengamatan & Variabel & KSZ & Sig. & Ket. \\
\hline \multirow{2}{*}{ Pretest } & RLPP & 0,598 & 0,866 & Normal \\
& Depresi & 0,688 & 0,731 & Normal \\
Posttest & RLPP & 0,529 & 0,942 & Normal \\
& Depresi & 0,598 & 0,867 & Normal \\
\hline
\end{tabular}

Tabel 4 menunjukkan bahwa hasil perhitungan normalitas kelompok aerobik pada data RLPP dan tingkat depresi saat pengamatan pretest maupun posttest didapatkan nilai signifikansi lebih besar dari 0,05 ( $p>0,05)$, maka dapat dinyatakan bahwa data penelitian pada kelompok aerobik berdistribusi normal. Hasil perhitungan normalitas kelompok yoga pada data RLPP dan tingkat depresi saat pengamatan pretest maupun posttest didapatkan nilai signifikansi lebih besar dari $0,05(p>0,05)$, maka dapat dinyatakan bahwa data penelitian pada kelompok yoga berdistribusi normal. Hasil perhitungan normalitas kelompok tanpa perlakuan pada data RLPP dan tingkat depresi saat pengamatan pretest maupun posttest didapatkan nilai signifikansi lebih besar dari 0,05 $(p>0,05)$, maka dapat dinyatakan bahwa data penelitian pada kelompok tanpa perlakuan berdistribusi normal.

\section{Uji Homogenitas}

Uji homogenitas digunakan untuk menguji kesamaan varians data hasil pengamataan pada masing-masing kelompok perlakuan. Uji homogenitas dilakukan pada data penelitian hasil pengamatan posttest karena data posttest yang digunakan untuk menjawab hipotesis penelitian. Tes statistik yang digunakan untuk menguji homogenitas varians adalah uji-F, yaitu membandingkan varians terbesar dengan varians terkecil. Pembacaan hasil data dikatakan homogen apabila $p$ value (Sig.) $>0,05$.

Tabel 5. Hasil Uji Homogenitas Data Kelompok

Kelompok Aerobik

\begin{tabular}{|c|c|c|c|c|}
\hline Variabel & Pengamatan & $\begin{array}{c}\mathrm{F} \\
\text { hitung }\end{array}$ & Sig. & Ket. \\
\hline RLPP & $\begin{array}{l}\text { Pretest } \\
\text { Posttest }\end{array}$ & 0,032 & 0,858 & Homogen \\
\hline $\begin{array}{l}\text { Depresi } \\
\text { Kelompok }\end{array}$ & $\begin{array}{l}\text { Pretest } \\
\text { Yoga }\end{array}$ & 0,082 & 0,776 & Homogen \\
\hline Variabel & Pengamatan & $\begin{array}{c}\mathrm{F} \\
\text { hitung }\end{array}$ & Sig. & Ket. \\
\hline RLPP & $\begin{array}{l}\text { Pretest } \\
\text { Posttest }\end{array}$ & 0,064 & 0,802 & Homogen \\
\hline $\begin{array}{l}\text { Depresi } \\
\text { Kelompok }\end{array}$ & $\begin{array}{l}\text { Pretest } \\
\text { Tanpa Perlak }\end{array}$ & $\begin{array}{l}3,246 \\
\text { uan }\end{array}$ & 0,080 & Homogen \\
\hline & Pengamatan & $\begin{array}{c}\mathrm{F} \\
\text { hitung }\end{array}$ & Sig. & Ket. \\
\hline RLPP & $\begin{array}{l}\text { Pretest } \\
\text { Posttest }\end{array}$ & 0,343 & 0,562 & Homogen \\
\hline Depresi & $\begin{array}{l}\text { Pretest } \\
\text { Posttest }\end{array}$ & 0,022 & 0,882 & Homogen \\
\hline
\end{tabular}

Hasil uji homogenitas pada Tabel 5, untuk menguji kesamaan varians hasil pengukuran data pada saat pretest dan posttest kelompok aerobik. Hasil uji homogenitas pada data RLPP, diperoleh nilai $\mathrm{F}$ hitung sebesar 0,032 dengan nilai signifikansi sebesar 0,858. Pada data tingkat depresi diperoleh nilai $\mathrm{F}$ hitung sebesar 0,082 dengan nilai signifikansi sebesar 0,776 . Oleh karena hasil uji homogenitas pada data RLPP dan tingkat depresi didapatkan nilai signifikansi lebih besar dari $0,05(p>0,05)$, maka dapat dinyatakan bahwa data pada kelompok aerobik adalah homogen. Hasil uji homogenitas untuk menguji kesamaan varians hasil pengukuran data pada saat pretest dan posttest kelompok yoga. Hasil uji homo- 
genitas pada data RLPP, diperoleh nilai $\mathrm{F}$ hitung sebesar 0,064 dengan nilai signifikansi sebesar 0,802 . Pada data tingkat depresi diperoleh nilai $\mathrm{F}$ hitung sebesar 3,246 dengan nilai signifikansi sebesar 0,080. Oleh karena hasil uji homogenitas pada data RLPP dan tingkat depresi didapatkan nilai signifikansi lebih besar dari 0,05 $(p>0,05)$, maka dapat dinyatakan bahwa data pada kelompok yoga adalah homogen. Hasil pengukuran data pada saat pretest dan posttest kelompok tanpa perlakuan. Hasil uji homogenitas pada data RLPP, diperoleh nilai $F$ hitung sebesar 0,343 dengan nilai signifikansi sebesar 0,562. Pada data tingkat depresi diperoleh nilai $\mathrm{F}$ hitung sebesar 0,022 dengan nilai signifikansi sebesar 0,882 . Oleh karena hasil uji homogenitas pada data RLPP dan tingkat depresi didapatkan nilai signifikansi lebih besar dari 0,05 ( $p>0,05)$, maka dapat dinyatakan bahwa data pada kelompok tanpa perlakuan adalah homogen.

\section{Uji Kesetaraan}

Uji kesetaraan dilakukan untuk mengetahui kondisi awal RLPP dan tingkat depresi pada wanita perimenopause sebelum diberikan perlakuan adalah sama, sehingga apabila terjadi perubahan RLPP dan tingkat depresi benar-benar dipengaruhi oleh perlakuan yang dilakukan. Uji kesetaraan dilakukan dengan melakukan uji ANOVA pada data pretest atau data sebelum diberikan perlakuan.

Tabel 6. Hasil Uji ANOVA Pretest

\begin{tabular}{lcccc}
\hline RLPP & \multicolumn{3}{c}{} \\
\hline Kelompok & Rerata & $\begin{array}{c}\text { F } \\
\text { hitung }\end{array}$ & Sig. & Ket. \\
\hline Aerobik & 0,905 & & & Tidak \\
Yoga & 0,908 & 0,252 & 0,778 & signifikan \\
Kontrol & 0,904 & & & \\
Depresi & & & & Ket. \\
Kelompok & Rerata & F & Sig. & \\
$\begin{array}{l}\text { Aerobik } \\
\text { Yoga }\end{array}$ & 5,25 & & & Tidak \\
Tanpa & 7,55 & 4,355 & 0,074 & signifikan \\
latihan & & & & \\
\hline
\end{tabular}

Berdasarkan Tabel 6, hasil analisis ANOVA pada data pretest RLPP didapatkan nilai $\mathrm{F}$ hitung sebesar 0,252 dan nilai signifikansi sebesar 0,778. Oleh karena nilai signifikansi hasil pengujian data pretest RLPP tersebut lebih besar dari 0,05 ( $p>0,05)$, maka dapat disimpulkan tidak terdapat perbedaan RLPP pada wanita perimenopause sebelum perlakuan. Artinya RLPP wanita perimenopause dari ketiga kelompok berada dalam kondisi yang sama. Hasil analisis ANOVA pada data pretest depresi didapatkan nilai $\mathrm{F}$ hitung sebesar 4,355 dan nilai signifikansi sebesar 0,074 . Oleh karena nilai signifikansi hasil pengujian data pretest depresi tersebut lebih besar dari $0,05(p>0,05)$, maka dapat disimpulkan tidak terdapat perbedaan depresi pada wanita perimenopause sebelum perlakuan. Artinya depresi wanita perimenopause dari ketiga kelompok berada dalam kondisi yang sama.

Hasil uji ANOVA untuk mengetahui latihan yang paling efektif menurunkan RLPP dapat dilihat pada Tabel 7.

Tabel 7. Hasil Uji ANOVA Posttest

\begin{tabular}{|c|c|c|c|c|}
\hline \multicolumn{5}{|l|}{ RLPP } \\
\hline Kelompok & Rerata & $\begin{array}{c}\mathrm{F} \\
\text { hitung }\end{array}$ & Sig. & Ket. \\
\hline $\begin{array}{l}\text { Aerobik } \\
\text { Yoga } \\
\text { Kontrol } \\
\text { Depresi }\end{array}$ & $\begin{array}{l}0,905 \\
0,908 \\
0,901\end{array}$ & 0,252 & 0,778 & $\begin{array}{c}\text { Tidak } \\
\text { Signifikan }\end{array}$ \\
\hline Kelompok & Rerata & $\begin{array}{c}\text { F } \\
\text { hitung }\end{array}$ & Sig. & Ket. \\
\hline $\begin{array}{l}\text { Aerobik } \\
\text { Yoga } \\
\text { Kontrol }\end{array}$ & $\begin{array}{l}4,50 \\
3,85 \\
5,08\end{array}$ & 11,344 & 0,000 & Signifikan \\
\hline
\end{tabular}

Berdasarkan Tabel 7, hasil analisis ANOVA pada data RLPP didapatkan nilai $F$ hitung sebesar 0,252 dan nilai signifikansi sebesar 0,778. Oleh karena nilai signifikansi hasil pengujian data RLPP tersebut lebih besar dari $0,05(p<0,05)$, maka dapat disimpulkan tidak terdapat perbedaan efektivitas latihan terhadap penurunan RLPP pada wanita perimenopause. Berdasarkan hasil analisis didapatkan nilai rerata RLPP pada kelompok aerobik sebesar 0,905, nilai rerata pada kelompok yoga sebesar 0,908 dan nilai rerata pada kelompok tanpa latihan sebesar 0,901. Hasil tersebut menunjukkan tidak ada kelompok yang lebih efektif diantara ketiga kelompok dalam menurunkan menurunkan RLPP pada wanita perimenopause.

Berdasarkan hasil analisis ANOVA pada data tingkat depresi didapatkan nilai $\mathrm{F}$ hitung sebesar 11,344 dan nilai signifikansi sebesar 0,000. Oleh karena nilai signifikansi hasil pengujian data RLPP tersebut lebih kecil dari $0,05(p<0,05)$, maka dapat disimpulkan terdapat perbedaan efektivitas latihan terhadap penurunan tingkat depresi pada wanita perimenopause. Berdasarkan hasil analisis didapatkan nilai rerata tingkat depresi pada kelompok aerobik sebesar 4,50 , nilai rerata pada kelompok yoga sebesar 3,85 dan nilai rerata pada kelompok tanpa latihan sebesar 5,08. Hasil tersebut menunjukkan nilai 
rerata pada kelompok yoga menunjukkan nilai rerata yang paling rendah, sehingga dapat disimpulkan yoga paling efektif menurunkan tingkat depresi pada wanita perimenopause.

Selanjutnya dilakukan uji t after Anova, untuk mengetahui perbedaan pada antar kelompok perlakuan pada Tabel 8 .

Tabel 8. Hasil Uji t After ANOVA Depresi

\begin{tabular}{lccc}
\hline Kelompok & Aerobik & Yoga & Kontrol \\
\hline Aerobik & 1 & 0,339 & $0,001^{*}$ \\
Yoga & 0,339 & 1 & $0,000^{*}$ \\
Kontrol & $0,001^{*}$ & $0,000^{*}$ & 1 \\
\hline
\end{tabular}

Berdasarkan Tabel 8, diketahui depresi kelompok aerobik tidak berbeda signifikan dengan kelompok yoga. Tingkat depresi kelompok aerobik berbeda signifikan dengan kelompok tanpa latihan. Tingkat depresi kelompok yoga berbeda signifikan dengan kelompok tanpa latihan.

\section{Pengujian Hipotesis}

Hipotesis I penelitian ini berbunyi "Senam aerobik dan yoga efektif untuk penurunan RLPP dan tingkat depresi pada wanita perimenopause".pengujian hipotesis 1 dilakukan menggunakan uji t paired sample t test. Hasil analisis data pengujian hipotesis 1 penenelitian ini bisa dilihat pada Tabel 9.

Berdasarkan Tabel 9, hasil analisis uji $\mathrm{t}$ pada data RLPP didapatkan nilai t hitung sebesar
1,357 dan nilai signifikansi sebesar 0,191. Hasil uji t pada data tingkat depresi didapatkan nilai $t$ hitung sebesar 1,958 dan nilai signifikansi sebesar 0,065. Oleh karena nilai signifikansi hasil pengujian pada data RLPP dan tingkat depresi tersebut lebih besar dari 0,05 ( $p>0,05)$, maka dapat disimpulkan aerobik tidak efektif untuk penurunan RLPP dan tingkat depresi pada wanita perimenopause, sehingga hipotesis pertama penelitian ini ditolak. Hasil analisis uji t pada data RLPP didapatkan nilai t hitung sebesar 1,435 dan nilai signifikansi sebesar 0,168 . Hasil uji t pada data tingkat depresi didapatkan nilai t hitung sebesar 4,013 dan nilai signifikansi sebesar 0,001 . Oleh karena nilai signifikansi hasil pengujian pada data tingkat depresi tersebut lebih kecil dari 0,05 ( $p>0,05)$, maka dapat disimpulkan yoga tidak efektif untuk menurunkan RLPP tetapi efektif untuk menurunkan tingkat depresi pada wanita perimenopause, sehingga hipotesis penelitian ini diterima.

Berdasarkan hasil analisis uji t pada data RLPP didapatkan nilai t hitung sebesar 1,957 dan nilai signifikansi sebesar 0,065 . Hasil uji t pada data tingkat depresi didapatkan nilai $\mathrm{t}$ hitung sebesar 0,954 dan nilai signifikansi sebesar 0,352 . Oleh karena nilai signifikansi hasil pengujian pada data RLPP dan tingkat depresi tersebut lebih besar dari 0,05 ( $p>0,05)$, maka dapat disimpulkan tidak terdapat perbedaan RLPP dan tingkat depresi pada kelompok yang tidak diberi perlakuan.

Tabel 9. Hasil Uji t Data Kelompok

\begin{tabular}{|c|c|c|c|c|c|}
\hline \multicolumn{6}{|l|}{ Aerobik } \\
\hline Variabel & Pengamatan & Rerata & t hitung & Sig. & Ket. \\
\hline RLPP & $\begin{array}{l}\text { Pretest } \\
\text { Posttest }\end{array}$ & $\begin{array}{l}0,904 \\
0,899\end{array}$ & 1,357 & 0,191 & Tidak Signifikan \\
\hline Depresi & $\begin{array}{l}\text { Pretest } \\
\text { Posttest }\end{array}$ & $\begin{array}{l}5,25 \\
4,50\end{array}$ & 1,958 & 0,065 & Tidak Signifikan \\
\hline \multicolumn{6}{|l|}{ Yoga } \\
\hline Variabel & Pengamatan & Rerata & t hitung & Sig. & Ket. \\
\hline RLPP & $\begin{array}{l}\text { Pretest } \\
\text { Posttest }\end{array}$ & $\begin{array}{l}0,908 \\
0,905\end{array}$ & 1,435 & 0,168 & Tidak signifikan \\
\hline Depresi & $\begin{array}{l}\text { Pretest } \\
\text { Posttest }\end{array}$ & $\begin{array}{l}5,50 \\
3,85\end{array}$ & 4,013 & 0,001 & Signifikan \\
\hline \multicolumn{6}{|c|}{ Tanpa Perlakuan } \\
\hline Variabel & Pengamatan & Rerata & thitung & Sig. & Ket. \\
\hline RLPP & $\begin{array}{l}\text { Pretest } \\
\text { Posttest }\end{array}$ & $\begin{array}{l}0,901 \\
0,895\end{array}$ & 1,957 & 0,065 & Tidak signifikan \\
\hline Depresi & $\begin{array}{l}\text { Pretest } \\
\text { Posttest }\end{array}$ & $\begin{array}{l}7,30 \\
6,90 \\
\end{array}$ & 0,954 & 0,352 & Tidak signifikan \\
\hline
\end{tabular}




\section{Pembahasan}

Pengaruh Senam Aerobik dan Yoga terhadap Penurunan RLPP dan Tingkat Depresi pada Wanita Perimenopause

Hasil analisis menunjukkan bahwa senam aerobik tidak berpengaruh terhadap penurunan RLPP dan tingkat depresi pada wanita. Pemberian perlakuan senam aerobik pada wanita perimenopause belum mampu menurunkan RLPP dan tingkat depresi pada wanita perimenopause secara signifikan. Senam aerobik merupakan salah satu bentuk aktivitas fisik dalam bentuk gerakan berirama dan dinamis. Senam aerobik bertujuan untuk meningkatkan kebugaran tubuh dan juga sebagai sarana sekaligus untuk mendapatkan kesenangan. Senam aerobik merupakan salah satu cara untuk meningkatkan kebugaran.

Senam aerobik tidak berpengaruh terhadap RLPP wanita perimenopause dapat dijelaskan karena pada wanita perimenopuase yang telah memasuki usia $>45$ tahun mengalami penurunan metabolisme tubuh. Hal ini menyebabkan pembakaran kalori pada waktu melakukan olahraga lebih rendah dibandingkan saat masih berusia muda. Pemberian perlakuan senam aerobik yang dilakukan selama penelitian belum mampu menurunkan RLPP. Selain itu juga dipengaruhi oleh faktor lain yang tidak dikendalikan dalam penelitian seperti faktor pola makan dan gaya hidup responden. Wanita perimenopause yang melakukan aerobik secara rutin tetapi tidak mengatur pola makan dan gaya hidup sehat, maka penurunan RPLPP menjadi kurang efektif.

Secara teori yang dikemukakan oleh Sadoso (2001, p.3), menyebutkan bahwa gerakan dalam senam aerobik mampu membakar lemak dan kalori di dalam tubuh juga memperlancar proses pembuangan keringat. Aktivitas gerak senam dalam senam aerobik mempunyai fungsi yang salah satu diantaranya adalah agar mampu membakar kadar lemak dalam tubuh. Senam aerobik tersebut akan efektif menurunkan RLPP apabila disertai dengan pengaturan pola makan dan gaya hidup sehat. Senam aerobik juga tidak berpengaruh terhadap penurunan tingkat depresi pada wanita perimenopause. Hal ini dapat dijelaskan karena saat memasuki usia perimenopause wanita mengalami berbagai perubahan baik secara fisik maupun psikologis. Kondisi tersebut mempengaruhi gejolak emosi wanita perimenopause sehingga melakukan senam aerobik saja tidak cukup untuk menurunkan depresi yang dirasakan.
Secara teori yang dikemukakan oleh Brick (2001, p. 3), menyebutkan bahwa senam aerobik merupakan salah satu jenis kegiatan rekreatif yang banyak digemari karena menyenangkan. Senam aerobik dapat menjadi sarana rekreasi. Senam merupakan aktivitas yang menyenangkan untuk dilakukan. Wanita perimenopause yang mengikuti senam aerobik akan mendapatkan perasaan senang sehingga dapat menurunkan tingkat depresi yang dirasakan, akan tetapi saat kondisi emosional tidak stabil dan banyak perubahan dalam diri maka wanita perimenopause membutuhkan waktu untuk menyesuaikan diri terhadap perubahan pada dirinya. Senam aerobik dapat menjadi salah satu sarana rekreasi tetapi belum mampu menurunkan depresi yang dialami secara signifikan. Bertemu dengan teman yang senasib dapat meringankan beban sesaat. Didukung pendapat Sumosardjuno (2001, p.3), menyebutkan senam aerobik bermanfaat untuk meningkatkan mood dan mengurangi stress karena mampu mengaktifkan hormon endorphin sehingga tercipta perasaan senang dan sejahtera.

Hasil analisis juga diketahui bahwa yoga tidak berpengaruh terhadap penurunan RLPP dan tetapi berpengaruh tingkat depresi pada wanita perimenopause. Pada kelompok wanita perimenopause yang mengikuti yoga juga tidak mengalami penurunan RLPP tetapi mengalami penurunan tingkat depresi. Aktivitas yoga terbukti mampu menurunkan tingkat depresi pada wanita perimenopause.

Yoga merupakan suatu bentuk aktivitas fisik dengan melatih konsentrasi, mengontrol indra dan melatih pernafasan. Bagus (2011, p.110), menyebutkan yoga berarti mengendalikan, mengatur dan berkonsentrasi yang berfungsi menyelaraskan tubuh, jiwa dan pikiran manusia. Yoga mempunyai manfaat membentuk kebugaran tubuh. Yoga tidak berpengaruh terhadap penurunan RLPP pada wanita perimenopause dapat dijelaskan karena, yoga berfokus pada latihan konsentrasi dan pernafasan. Fokus yoga tidak pada pembakaran lemak, sehingga tingkat RLPP wanita perimenopause tidak mengalami penurunan secara signifikan. Yoga melatih kelentukan tubuh dengan gerakan-gerakan tertentu. Pada saat melakukan gerakan yoga, akan terjadi peregangan otot tubuh sehingga tubuh menjadi semakin lentur. Didukung pendapat Arovah, Sriwahyuniati, \& Listyarini, (2013, p.22), menyebutkan yoga melatih kelentukan melalui salah satu bagian dari yoga disebut asana yang terdiri dari gerakan stretching yang aman untuk otot. 
Yoga sangat bermanfaat pada ketenangan jiwa. Pembakaran lemak tubuh bukan menjadi fokus prioritas utama dari latihan yoga, sehingga saat melakukan yoga maka tidak terjadi pembakaran kalori yang signifikan. Dampaknya RLPP wanita perimenopause yang mengikuti yoga tidak mengalami penurunan. Sesuai pendapat Weller (2001, p.312), menyebutkan latihan pernafasan dalam yoga memainkan peran penting dalam metabolisme tubuh yaitu proses tubuh mengurai nutrisi.

Hasil analisis juga membuktikan bahwa yoga berpengaruh terhadap penurunan tingkat depresi pada wanita perimenopause. Yoga berpengaruh terhadap penurunan tingkat depresi pada wanita perimenopause dapat dijelaskan karena yoga fokus pada latihan konsentrasi, pernafasan, dan relaksasi sehingga dapat mengurangi depresi dan kecemasan. Seperti yang dikemukakan oleh Weller (2001, p.312), menyebutkan bahwa teknik senam yoga mengendalikan pernafasan dan pikuran yang dapat menguatkan pernafasan, menenangkan sistem saraf pusat dan membantu mengurangi dan menghilangkan ketegangan.

Salah satu aspek penting dalam yoga yang membantu menurunkan tingkat depresi pada wanita perimenopause adalah relaksasi. Relaksasi dalam yoga akan mampu menurunkan beban pikiran dan melepaskan ketegangan yang dirasakan sehingga menjadi lebih tenang. Didukung pendapat Worby (2007, p.226), menyebutkan manfaat nyata yang dapat dirasakan dari latihan yoga adalah berkurangnya kelelahan, pikiran dan emosi menjadi tenang. Latihan yoga berdampak positif terhadap sistem sirkulasi dalam tubuh menjadi normal. Salah satunya adalah sirkulasi darah dan sirkulasi oksigen menuju otak. Dampaknya adalah menimbulkan respon relaksasi yang membuat wanita perimenopause semakin terbebas dari beban yang dirasakan sehingga tingkat depresi semakin menurun. Sesuai dengan pendapat Worby (2007, p.229), menyebutkan bahwa latihan pernapasan dalam yoga memberikan dampak positif terhadap keseluruhan sistem sirkulasi dan jantung untuk beristirahat dan membuat tubuh menjadi semakin rileks.

Jenis Latihan Paling Efektif Menurunkan RLPP dan Tingkat Depresi pada Wanita

Perimenopause

Hasil analisis diketahui tidak ada yang lebih efektif dalam menurunkan RLPP diantara senam aeobik maupun yoga. Kedua jenis latihan sama-sama tidak dapat menurunkan RLPP secara signifikan. Hal ini dapat dijelaskan karena sistem metabolisme wanita perimenopause yang semakin menurun, sehingga latihan yang singkat saat perlakuan tidak mampu menurunkan RLPP secara signifikan.

Senam aerobik banyak digunakan untuk program penurunan berat badan. Hal ini karena saat mengikuti senam aerobik seluruh anggota tubuh akan aktif bergerak mengikuti irama yang dinamis sehingga akan terjadi proses pembakaran lemak dan kalori. Syaratnya yaitu harus dilakukan secara teratur dan diimbangi dengan mengatur pola makan dan gaya hidup sehat. Pada latihan yoga lebih menekankan pada gerakan peregangan atau stretching. Latihan ini akan bekerja pada otot yang dikenai gerakan peregangan tersebut. Pembakaran lemak dari latihan yoga lebih sedikit. Sumosardjuno (2001, p.3), menyebutkan bahwa mekanisme olahraga aerobik adalah mampu menurunkan lemak dalam tubuh. Senam aerobik merupakan aktivitas yang salah satu tujuan utamanya adalah menurunkan lemak tubuh melalui proses pembakaran lemak dari aktivitas gerak dinamis. Gerakan senam aerobik dirancang sedemikian rupa agar mampu membakar lemak dalam tubuh.

Kendala yang dihadapi dalam penelitian ini diantaranya tidak dapat dikendalikan faktor lain yang mempengaruhi RLPP diantaranya pola makan dan gaya hidup dari wanita perimenopuase. Walaupun telah melakukan latihan rutin, apabila pola makan tidak diatur maka penurunan RLPP menjadi sangat sulit. Selain itu juga terkendala pada wanita perimenopause yang sering absen mengikuti latihan sehingga tidak rutin melakukan aerobik maupun yoga. Hasil penelitian berbeda dengan penelitian yang dilakukan oleh penelitian sebelumnya yang dilakukan oleh Sientia, \& Puruhita (2012, p.23), dengan hasil penelitian terdapat pengaruh senam aerobik terhadap penurunan berat badan pada peserta klub kebugaran dan setelah mengikuti latihan senam aerobik selama 12 minggu di klub kebugaran. Hasil penelitian sebelumnya menunjukkan bahwa senam aerobik efektif digunakan untuk menurunkan berat badan atau dalam penelitian ini menurunkan RLPP pada wanita perimenopause. Hasil analisis diketahui yoga lebih efektif menurunkan tingkat depresi pada wanita perimenopause. Hasil ini dapat dijelaskan karena di dalam yoga terdiri dari beberapa komponen diantaranya adalah latihan pernafasan dan rileksasi. Bentuk latihan nafas dan rileksasi sangat berperan dalam menurunkan tingkat depresi pada wanita perimenopause. 
Yoga dilakukan dengan teknik pernafasan yang mendalam sehingga dapat berfokus pada fikiran, pemusatan perhatian yang membuat menjadi lebih tenang. Teknik pernafasan pada yoga juga dapat meningkatkan fungsi kerja syaraf, merangsang pelepasan oksitosin sehingga memberikan efek relaksasi dan depresi yang dirasakan oleh wanita perimenopause semakin menurun. Yoga juga dapat menurunkan hormon penyebab stress. Mekanisme kerja berasal dari latihan pernafasan dan relaksasi dalam yoga. Penurunan kadar hormon penyebab stress akan meningkatkan ketenangan jiwa. Aktivitas yoga juga dapat meningkatkan hormon endorphin yang menimbulkan perasaan senang sehingga depresi semakin berkurang.

Dibandingkan dengan senam aerobik, yoga lebih efektif menurunkan tingkat depresi pada lansia. Seluruh komponen gerak yoga difokuskan pada pemusatan pikiran, konsentrasi, pernafasan dan relaksasi yang memberikan dampak nyata terhadap aspek psikis wanita perimenopause. Sedangkan senam aerobik lebih menekankan pada aktivitas fisik, sehingga pengaruhnya terhadap penurunan depresi lebih kecil dibandingkan dengan yoga. Dapat disimpulkan yoga lebih efektif menurunkan tingkat depresi pada wanita perimenopause. Didukung pendapat dari Singh, Kyizom, Singh, Tandon, \& Madhu, (2008, p.365), menyebutkan bahwa senam yoga potensial memiliki manfaat klinis yang lebih baik dibandingkan dengan senam aerobik, karena yoga juga memberikan dampak relaksasi tubuh dan relaksasi pikiran yang dirasakan langsung pada saat latihan yang ditunjang oleh latihan pernafasan, konsentrasi dan relaksasi. Pada saat melakukan yoga tubuh dan pikiran menjadi rileks dan tenang sehingga masalah psikis seperti stress, cemas dan depresi dapat menurun.

Hasil penelitian ini juga didukung oleh penelitian sebelumnya yang dilakukan oleh Yulian, Aini, \& Choiriyyah (2013, p.19), didapatkan hasil penelitian bahwa senam yoga berpengaruh terhadap penurunan tingkat kecemasan ibu premenopause di Desa Leyangan, Ungaran Timur, Semarang. Kesamaan hasil penelitian ini yaitu wanita perimenopause mengalami penurunan kecemasan dan depresi secara signifikan setelah mengikuti yoga. Dapat disimpulkan bahwa yoga efektif digunakan untuk menurunkan tingkat depresi pada wanita perimenopause.

\section{SIMPULAN}

Berdasarkan hasil analisis data dan pembahasan yang telah dilakukan, kesimpulan penelitian ini adalah sebagai berikut: (1) Senam aerobik tidak efektif untuk menurunkan Rasio Lingkar Pinggang Panggul (RLPP) dan tingkat depresi pada wanita perimenopause $(p>0,05)$. Yoga tidak efektif menurunkan RLPP $(p>0,05)$, tetapi efektif menurunkan tingkat depresi $(p<0,05)$. (2) Tidak ada jenis latihan yang lebih efektif menurunkan RLPP pada wanita perimenopause. Jenis latihan yang lebih efektif menurunkan tingkat depresi pada wanita perimenopause adalah yoga.

\section{DAFTAR PUSTAKA}

Arovah, N. I., Sriwahyuniati, C. F., \& Listyarini, E. (2013). Pengembangan model senam yoga untuk kontrol glukosa darah dan menurunkan resiko komplikasi penderita diabetes mellitus tipe 2 (Suatu tinjauan klinis dan sosio-psikologis). Yogyakarta. Retrieved from https://eprints.uny.ac.id/22510/

Bagus, D. (2011). Komitmen karyawan: Definisi dan jenis komitmen karyawan. Jurnal Manajemen, Bahan Kuliah Manajemen, retrived from: http://jurnalsdm.blogspot.com/2009/07/komitmenkaryawan-definisi-dan-jenis.html

Brick, L. (2001). Bugar dengan senam aerobik. Jakarta: PT Raja Gasindo Persada.

Budiyono, K. (2015). Amplikasi senam aerobic high impact dan low impact terhadap penurunan presentase lemak tubuh pada kepala sekolah dasar se-Kecamatan Banjarsari Surakarta. Jurnal Ilmiah SPIRIT, 15(1). Retrived from: http://ejournal.utp.ac.id/index.php/JIS/arti cle/view/293

Dinata, M. (2007). Langsing dengan aerobik. Jakarta: Cerdas Jaya.

Fatmah, R.Y. (2011). Gizi kebugaran dan olahraga. Bandung: Lubuk Agung.

Kaplan, H. I., Sadock, B. J., \& Grebb, J. A. (2010). Sinopsis psikiatri: Ilmu pengetahuan perilaku psikiatri klinis. Dr. I. Made Wiguna S. Jakarta: Bina Rupa Aksara.

Mawi, M., Tandean, R., Hermawan, J., Rahmawati, M. R., Merijanti, L. T., \& Abikusno, N. (2009). Pengaruh olahraga aerobik terhadap kadar estradiol pada wanita pasca menopose: studi randomsasi selama 12 minggu. Universal Medicine, 25(3). 
Putri, A. K., \& Hamidah, H. (2012). Hubungan Antara Penerimaan Diri dengan Depresi pada Wanita Perimenopause. Jurnal Psikologi Klinis dan Kesehatan Mental, 1(02), 1-6

Sadoso, S. (2001). Pengetahuan praktis kesehatan dan olahraga. Jakarta: PT. Gramedia.

Sientia, F., \& Puruhita, N. (2012). Pengaruh latihan senam aerobik terhadap perubahan berat badan pada peserta klub kebugaran. Jurnal Kedokteran Diponegoro, 1(1). Retrieved from https://ejournal3.undip.ac.id/index.php/me dico/article/view/1707

Singh, S., Kyizom, T., Singh, K. P., Tandon, O. P., \& Madhu, S. V. (2008). Influence of pranayamas and yoga-asanas on serum insulin, blood glucose and lipid profile in type 2 diabetes. Indian Journal of Clinical Biochemistry, 23(4), 365-368. https://doi.org/10.1007/s12291-008-00809

Weller, M. T. (2001). Inorganic materials chemistry. Oxford University Press.

Worby, C. (2007). Memahami segalanya tentang yoga: Tingkat kekuatan, kelenturan, dan kesehatan anda (SC Simanjuntak, trans). Yoga: Everything yoga book. Jakarta: Karisma Publishing Group.

Yulian, S., Aini, F., \& Choiriyyah, Z. (2013). Pengaruh senam yoga terhadap penurunan tingkat kecemasan ibu premenopause di Desa Leyangan Kecamatan Ungaran Timur Kabupaten Semarang. Ungaran. 